TẠP CHÍ KHOA HỌC ĐẠI HỌC ĐÀ LẠT T Tập 10, Số 1, 2020 114-128

\title{
TRAO ĐỔI THÊM VỀ THỜI ĐIỂM RA ĐỜI CỦA TÍN NGỮ̛̃NG THỜ MẪU TAM PHỦ
}

\author{
Cao Thế Trình ${ }^{\mathrm{a}^{*}}$ \\ ${ }^{a}$ Khoa Quốc tế học, Truờng Đại học Đà Lạt, Lâm Đồng, Việt Nam \\ *Tác giả liên hệ: Email: trinhct@dlu.edu.vn \\ Lịch sử bài báo \\ Nhận ngày 16 tháng 11 năm 2019 \\ Chỉnh sửa ngày 20 tháng 02 năm 2020 | Chấp nhận đăng ngày 24 tháng 02 năm 2020
}

\section{Tóm tắt}

Trên co sở phân tích các dũ liệu huyền thoại, các đạo sắc phong, và bối cảnh lịch sử, tác giả bài báo cho rằng tín nguỡng thờ Mẫu nói chung có thể ra đời sớm và gắn với khát vong phồn thưc của cu dân nông nghiệp, còn tín nguỡng thờ Mẫu Tam phủ là tục thờ vị Nũ thần Tài Lộc của tầng lớp nũ tiểu thương, gắn với nhu cầu về một vị nũ thần phù trọ," "ban tài phát lộc" cho nhũng ngườ làm nghề buôn bán. Do vậy, tín nguõng thò̀ Mẫu Tam phủ không thể xuất hiện sớm hơn thời điểm đầu thế kỷ thứ XVII, bởi các nguồn tài liệu thu tịch của Việt Nam và các giáo sỹ phuoong Tây thời đó đều chưa đề cập tới huyền thoại và hiẹn tuợng thờ Mẫu Liễu ở Đàng Ngoài. Là loại hình tín nguõng hình thành và phát triển trên co sở hoạt động buôn bán nhỏ lẻ, nên khi đất nước vận hành nền kinh tế theo cơ chế thị trưòng, nó đã bùng phát mạn mẽ cả về co sở thờ tụ và hoạt động lên đồng-hầu bóng, gây lãng phí về thời gian, tiền của, và sức khỏe của tín đồ. Để tín ngưỡng thờ Mẫu phát triển lành mạnh đúng với bản chất tốt đẹp của nó, theo tác giả cần hết súc cảnh giác với hiện tuợng "thuơng mại hóa" hoạt động thờ Mẫu nói chung và lên đồng nói riêng.

Từ khóa: Thánh Mẫu; Thánh Mẫu Liễu Hạnh; Tín ngưỡng dân gian; Tín ngưỡng thờ Mẫu Tam phủ/Tứ phủ.

DOI: http://dx.doi.org/10.37569/DalatUniversity.10.1.616(2020)

Loại bài báo: Bài báo nghiên cứu gốc có bình duyệt

Bản quyền @ 2020 (Các) Tác giả.

Cấp phép: Bài báo này được cấp phép theo CC BY-NC 4.0 


\title{
MORE DISCUSSION ABOUT THE TIME OF APPEARANCE OF VIET BELIEFS IN THE MOTHER GODDESSES OF THREE REALMS
}

\author{
Cao The Trinh ${ }^{\mathrm{a}}$ \\ ${ }^{a}$ The Faculty of International Studies, Dalat University, Lamdong, Vietnam \\ *Corresponding author: Email: trinhct@dlu.edu.vn \\ Article history \\ Received: November $16^{\text {th }}, 2019$ \\ Received in revised form: February $20^{\text {th }}, 2020 \mid$ Accepted: February $24^{\text {th }}, 2020$
}

\begin{abstract}
On the basis of the analysis of myths, old royal decrees (sắc phong) and historical texts, the author argues that the worship of the Mother Goddesses could have appeared as early as associated beliefs in fertility by agricultural residents. It is thought that the belief in the Mother Goddesses of Three Realms is a custom linked to the worship of the God of Wealth by the small business class, associated with the need for an assistant goddess to give fortune to those who work as business people. Therefore, the belief in the Mother Goddesses of Three Realms could not have appeared earlier than the beginning of the seventeenth century because the documentation of Vietnamese authors and Western clergy at that time did not mention the myth and worship of the Lieu Hanh Mother in the Kingdom of Tonqueen (Đàng ngoài). This kind of worship was considered a belief system formed and developed on the basis of small business activities. When the country's economy operated under market mechanisms, this belief system expanded strongly in both temples and shaman rituals (lên đồng), which are considered a waste of the time, money and health of believers. In order for the belief in the Mother Goddesses of Three Realms to develop in a healthy manner in accordance with its good nature, according to the author, it is necessary to be very cautious about the "commercialization" of this belief system in general and shaman rituals (lên đồng) in particular.
\end{abstract}

Keywords: Folk beliefs; Mother Goddesses; Lieu Hanh Mother Goddesses; Vietnamese beliefs in the Mother Goddesses of Three Realms/Four Realms.

DOI: http://dx.doi.org/10.37569/DalatUniversity.10.1.616(2020)

Article type: (peer-reviewed) Full-length research article

Copyright $\odot 2020$ The author(s).

Licensing: This article is licensed under a CC BY-NC 4.0 


\section{MỞ ĐẦU}

Lâu nay, trong giới nghiên cứu tín nguỡng thờ Mẫu (TNTM) hay đạo Mẫu vẫn phổ biến quan niệm cho rằng loại hình tín ngưỡng này có nguồn cội sâu xa từ "tục thờ mẹ" của cư dân nông nghiệp lúa nước, được "lên khuôn" từ thế kỷ XV và định hình từ thế kỷ XVI (Bùi, 2015, tr. 241; Ngô, 2010, tr. 18; Ngô, 2016, tr. 3; Trần, 2017, tr. 112). Cũng theo đó, bối cảnh ra đời của TNTM là phản ứng xã hội trước sự khủng hoảng của ý thức hệ Nho giáo và phản ứng tự vệ trước sự xâm nhập của Ki tô giáo (Đặng, 2005, tr. 10-11; Nguyễn, 2001, tr. 178-179). Gắn với quan niệm trên "cái nôi" sinh thành của TNTM là Nam Định (Phủ Dày, huyện Vụ Bản, hoặc Phủ Nấp, huyện Ý Yên) có thể khẳng định: Quan niệm trên đây được xác lập chủ yếu dựa trên một số dị bản thứ cấp huyền thoại về "tam thế luân hồi" của Thánh Mẫu, có đối chiếu với Vân Cát thần nũ lục của Hồng Hà nữ sỹ Đoàn Thị Điểm (Đoàn, 2013, tr. 11-38) và một số tư liệu phái sinh khác như Cát Thiên tam thế thực luc, Quảng Cung linh tù bi ký, và Quảng Cung linh tù phả ký lưu giữ tại Phủ Nấp, xã Yên Đồng, huyện Ý Yên, Nam Định (Ngô, 2010). Liệu việc đồng nhất giữa huyền thoại với lịch sử như vậy có khách quan không? Đành rằng, rất khó xác định niên đại tuyệt đối cho các hiện tượng văn hóa, "sai số" có thể giao động hàng thập kỷ, thậm chí hàng thế kỷ, nhưng nhiệm vụ của giới khoa học là cố gắng càng tiệm cận hiện thực càng tốt, bởi chân lý là cụ thể. Với tinh thần đó, trên cơ sở phân tích một số tư liệu có tính xác thực cao từ thế kỷ XV đến thế kỷ XVII, bài báo này mạnh dạn nêu lên một số nhận thức của tác giả xung quanh vấn đề xác định thời điểm ra đời của TNTM.

\section{NỘI DUNG}

\subsection{Các khái niệm "Tín ngưỡng thờ Mẫu" và "Tín ngưỡng thờ Mẫu Tam phủ"}

Để xác định thời điểm ra đời của một loại hình tín ngưỡng nói chung, TNTM tam phủ nói riêng, trước hết cần xác định rõ khái niệm. Rõ ràng, cho đến nay ngay trong giới nghiên cứu vẫn tồn tại một cách hiểu "nhập nhằng" về khái niệm "tín ngưỡng thờ Mẫu" (GS. Ngô Đức Thịnh đề xuất danh xưng Đạo Mẫu-với tư cách là một hình thái tôn giáo sơ khai ở người Việt). Không phải ngẫu nhiên mà phần lớn các nhà nghiên cứu thường bắt đầu định nghĩa khái niệm này bằng việc giải thích từ nguyên của từ "Mẫu"-một từ gốc Hán với nghĩa phổ biến nhất hầu như mà ai cũng biết. Hiển nhiên vấn đề chúng ta đang bàn không liên quan tới phương diện từ nguyên học, bởi mục từ "Mẫu" (母) trong Tù điển Tù Hải có tới năm sắc thái ý nghĩa: Một là mẹ; Hai là từ chỉ người phụ nữ bậc trưởng bối (như bá mẫu, cô mẫu...); Ba là từ tôn xưng người phụ nữ luống tuổi (phiếu mẫu); Bốn là chỉ giống cái (như mẫu kê-"'gà mái”); và Năm là gốc của sự vật (như tụ mẫu-"chữ cái”, công tác mẫu $c o$-“máy cái”) (“Từ Hải”, 1979, tr. 1600).

Rõ ràng, cả năm sắc thái ý nghĩa trên đây đều không phù hợp với đối tượng chúng ta đang xem xét. Lý do khá đơn giản vì ở người Hán không có loại hình tín ngưỡng này. "Mẫu" ở đây không thể là "mẹ" theo nghĩa thế tục, bởi mẹ theo nghĩa đó đã thuộc về phạm trù thờ cúng tổ tiên (bao gồm cả ông-bà, cha-mẹ). "Mẫu" ở đây là cách gọi tắt từ Thánh Mẫu-từ dùng tôn xưng những liệt nữ và anh thư có công đức với 
dân chúng một vùng rộng lớn. Khi họ qua đời, theo quan niệm dân gian thì "âm đức" của họ vẫn còn che chở và phù trợ cho cuộc sống của bách tính, là mẫu thân/phu nhân của những nhân vật siêu quần, hoặc là nhũng nhân vật nũ̃ huyền thoại (goddesses) vẫn thường hiển linh "hộ quốc tý dân". Đó là những phụ nữ như mẹ của Thánh Gióng-Đổng Xung Thiên Thần Vưong Mẫu, là Tống hậu/Tống phi nuơng nưong, là Bà Chúa Kho, là Thiên Y A Na, là các Bà Chúa Xứ ở Nam Bộ... cho tới bà Thiên Hậu của người Hoa, hay Đức Mẹ đồng trinh Saint Maria cũng được tôn xưng là Thánh Mẫu. Đây là những vị Mẫu thần (Mother Goddesses) nói chung, có thể bắt gặp ở nhiều dân tộc trên thế giới và thậm chí xuất hiện từ thời tiền sử (Phạm, 2016, tr. 28-30).Trường hợp chúng ta đang xem xét là Mẫu Tam phủ/Tú phủ (Mother Godesses of Three Realms) một hiện tượng độc đáo và riêng có ở người Việt. Đạo giáo Trung Hoa cũng có quan niệm về Tam phủ (còn gọi là Tam giới/Tam nguyên) do ba vị nam thần (đại đế) cai quản là Thiên quan giáng phúc, Địa quan xá tội, và Thủy quan giải nguy. Ở người Việt, thuộc về "Tam phủ" gồm: Thiên phủ, Nhac phủ, và Thoải (Thủy) phủ. Trong trường hợp "Tứ phủ" sẽ gồm ba phủ nói trên cộng thêm một phủ nữa là Địa phủ, Nhân phủ, hay phủ Trần triều? Theo chúng tôi là phủ Trần triều (Do công nhận của UNESCO sử dụng danh xưng là "tín ngưỡng thờ Mẫu Tam phủ"-"Practices Related to the Viet Beliefs in the Mother Goddesses of Three Realms"). Nhân vật trung tâm là thần chủ của TNTM tam phủ là Thánh Mẫu Liễu Hạnh. Do vậy, khi đề cập tới sự ra đời của TNTM Tam phủ chính là xác định thời điểm xuất hiện của hiện tượng thờ Mẫu Liễu Hạnh, bởi nếu mở rộng ra, khi đó chúng ta sẽ "trượt" sang phạm trù thờ Mẫu thần nói chung.

Trong các nghiên cứu của mình, GS. Ngô Đức Thịnh nhiều lần đưa ra một sơ đồ về quá trình hình thành đạo Mẫu Tam phủ, Tứ phủ là quá trình phát triển từ tục thờ Nữ thần, qua Mẫu thần và đỉnh cao là tín ngưỡng thờ Mẫu Tam phủ/Tứ phủ (Ngô, 2009, tr. 34; Ngô, 2010, tr. 17), cụ thể trong Hình 1.

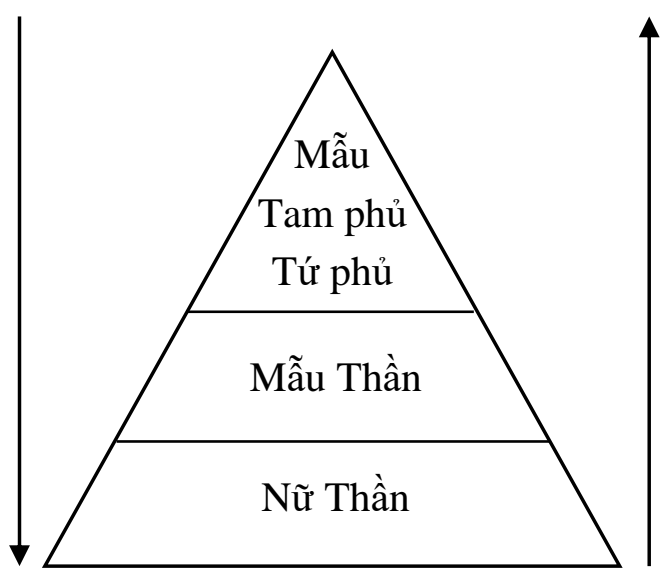

\section{Hình 1. Quá trình hình thành và phát triển Đạo Mẫu từ tục thờ Nữ Thần đến tín ngưỡng thờ Mẫu Tam Phủ/Tứ Phủ}

Theo chúng tôi, không hẳn TNTM Tam phủ là kết quả của một quá trình phát triển như vậy, bởi về cơ bản, Mẫu Liễu là $N \tilde{u}$ thần Tài Lộc của tầng lớp nữ tiểu thương, phân biệt với Mẫu thần nói chung của cư dân nông nghiệp. Đó cũng là lý do lý giải tại sao ở nhiều vùng thuần nông người dân thậm chí không biết gì về Mẫu Liễu Hạnh. 
Tóm lại, TNTM Tam phủ với vị thần chủ là Mẫu Liễu Hạnh là một loại hình tín ngưỡng mang tính độc lập nhất định, song song tồn tại cùng TNTM nói chung, tuy có tác động qua lại nhất định. Có thể hình dung qua Hình 2.

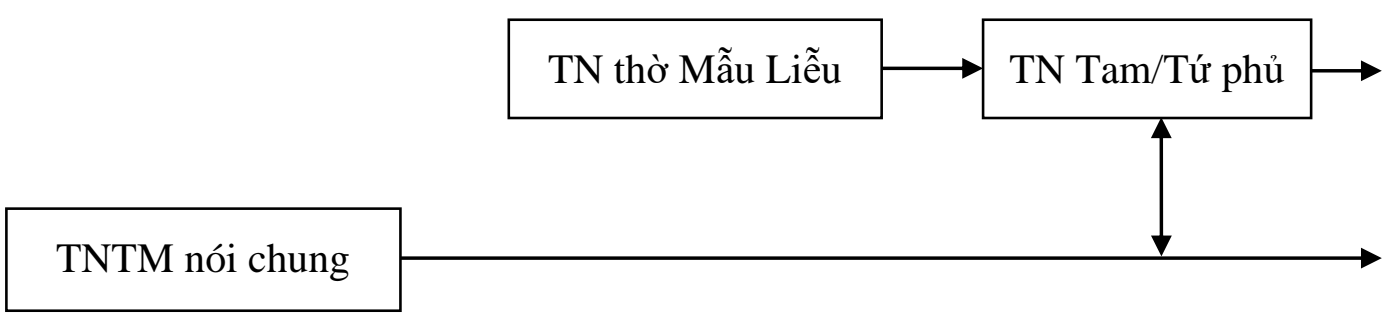

\section{Hình 2. Mỗi quan hệ giữa tín ngưỡng thờ Mẫu và tín ngưỡng Tam/Tứ Phủ}

Đành rằng mọi sự so sánh đều khập khễng, song để tiện hình dung tác giả mạnh dạn so sánh sự khác biệt giữa hai phạm trù TNTM và TNTM Tam phủ cũng tương tự như các phạm trù thơ và thơ mới, nhà cửa truyền thống và cao ốc, áo tứ thân và áo dài tân thời... TNTM nói chung là sản phẩm của tư tưởng dĩ nông vi bản và TNTM tam phủ là con đẻ của quan niệm phi thương bất phú.

\subsection{Xác định thời điểm xuất hiện của TNTM Tam phủ}

Để xác định thời điểm ra đời của một loại hình tín ngưỡng cũng cần phân biệt hai phạm trù: Thời điểm xuất hiện đối tượng thờ phụng trong quan niệm dân gian trong thực tế (thường được đẩy xa hơn so với thực tế) và thời điểm xuất hiện đối tượng thờ phụng và thời điểm hình thành tục thờ đối tượng. Chẳng hạn, theo quan niệm dân gian, các vua Hùng dựng nước Văn Lang cách đây hơn bốn ngàn năm (theo tính toán của các tác giả bộ Đại Việt Sư ký toàn thu là tương đương với năm 2879 TCN) (Lê, Phan, \& Ngô, 2003a, tr. 172). Trên thực tế, các nhà sử học chứng minh, Nhà nước Văn Lang chỉ xuất hiện vào khoảng thế kỷ VII TCN và tục thờ Hùng Vương còn xuất hiện muộn hơn nhiều (vào nửa sau thế kỷ XV, cụ thể là năm 1470). Hoặc giả, Phủ Tây Hồ (Hà Nội) được cho là có từ thế kỷ XVI gắn với tình tiết Tiên nữ Ngọc Quỳnh Hoa đối đáp thơ phú với Phùng Khắc Khoan, cử nhân họ Ngô, và tiến sỹ họ Lý trong chuyện Vân Cát thần nũ của Đoàn Thị Điểm, nhưng căn cứ vào lạc khoản trên hoành phi, câu đối, Chu Xuân Giao chứng minh nó chỉ được hình thành vào năm 1943 trên cơ sở trùng tu và chuyển đổi mục đích sử dụng đền Bảo Khánh đã có trước đó (Chu \& Phan, 2008, tr. 32-33).

Lâu nay, việc xác định thời điểm ra đời của TNTM Tam phủ chủ yếu được căn cứ vào huyền thoại và thiên hướng chung là chọn huyền thoại nào đề cập tới sự xuất hiện sớm nhất của Mẫu Liễu, làm căn cứ mà hầu như không đánh giá độ tin cậy của các thông tin trong huyền thoại đó. Điều đó đương nhiên là không khách quan, bởi như đã lưu ý ở trên, xu hướng chung của ký ức dân gian là đẩy sự xuất hiện của đối tượng thờ phụng sớm hơn so với thực tế, hay nói theo lời các nhà nghiên cứu Chu \& Phan $(2008$, tr. 26) là "truyền thống cổ hóa thời điểm xuất hiện". Chưa có một tác giả nào dựa vào những cứ liệu có độ tin cậy cao hơn, chẳng hạn như dựa vào thời gian xây dựng đền/phủ, dựa vào sắc phong/văn bia, hay một sử liệu đáng tin cậy nào đó để xác định thời điểm ra đời của loại hình tín ngưỡng này. Có thể do các cơ sở TNTM đã trải qua nhiều lần trùng tu và tôn tạo nên các tư liệu và di vật cổ hầu như đã thất thoát, một vài 
tấm bia hay các đạo sắc phong lại có niên đại muộn hơn so với "mong muốn”. Do vậy, "huyền tích" được xem là chỗ dựa quan trọng trong việc xác định thời điểm ra đời của loại hình tín ngưỡng này. Chúng tôi không hoàn toàn phủ nhận giá trị của các thông tin chứa đựng trong các huyền thoại, song vấn đề là phải đánh giá độ tin cậy của những thông tin đó, bởi gạt bỏ hay bóc tách lớp vỏ huyền thoại vẫn có thể nhận ra cái lõi sự thực tàng ẩn bên trong những huyền thoại. Bên cạnh đó, cần phân tích bối cảnh kinh tếxã hội và tìm những nguồn cứ liệu đáng tin cậy hơn để có thể tìm ra được thời điểm ra đời của TNTM Tam phủ một cách cụ thể nhất có thể.

\subsubsection{Nhìn lại hệ thống huyền thoại về Mẫu Liễu}

Hiếm có một nhân vật thờ phụng nào có được một hệ thống huyền thoại phong phú như Mẫu Liễu, thậm chí trở thành "một hiện tượng văn học đạo Mẫu" với một hệ thống thần tích, tiên thoại vừa truyền khẩu, vừa được "thư tịch hóa", vừa chữ Hán, vừa chữ Nôm, vừa chữ quốc ngữ, vừa dưới dạng văn xuôi, và vừa dưới dạng văn vần (GS. Ngô Đức Thịnh, vào năm 2009, sưu tập lại thành tập 2 bộ Đạo Mẫu Việt Nam với hơn 500 trang in khổ lớn, đương nhiên là vẫn chưa đầy đủ). Tuy vậy, phần lớn các huyền thoại đều có nội dung khá giống nhau, rất khó xác định đâu là nguyên bản, do vậy, chỉ nên xem tất cả đều là dị bản. Căn cứ vào thời gian, địa điểm, và số lần giáng sinh, tác giả quy các huyền thoại về Mẫu Liễu thành ba dị bản chính như sau:

- Dị bản a là Sự tích công chúa Liễu Hạnh được lưu truyền trong dân gian và được Nguyễn Đổng Chi sưu tập trong Kho tàng truyện cổ tích Việt Nam (ngoại trừ phần Khảo dị có nội dung tương tự với Dị bản b) (Nguyễn, 2000);

- Dị bản b là Vân Cát thần nũ luc trong Truyền kỳ tân phả của Hồng Hà nữ sỹ Đoàn Thị Điểm (1705-1748) (Đoàn, 2013);

- Dị bản c là Quảng Cung linh tù̀ phả ký của Vũ Huy Trác biên soạn năm 1781, Cát Thiên tam thế thực lục do Đoàn Triển và các Nho sinh biên soạn và được khắc in năm 1913, hiện lưu tại phủ Quảng Cung/Phủ Nấp, Ý Yên, Nam Định (Ngô, 2010).

Ngoài ra ở Phủ Nấp còn có tấm bia Quảng Cung linh tù bi do Nguyễn Đình Việp khắc dựng năm 1741, song cần xác minh niên đại và tác giả; Tấm bia hiện tại mới khắc lại năm 2001 (Chu, 2010, tr. 120). Sự khác nhau giữa các dị bản nói trên là về thời gian giáng sinh (lần đầu) vào các năm 1429,1434 , hoặc 1557 , về địa chỉ và số lần giáng sinh, về tên cha mẹ (lúc đầu thai), về tính danh và gia thất của Tiên Chúa. Có thể hình dung sự khác biệt đó qua Bảng 1 . 


\section{Bảng 1. So sánh ba dị bản huyền thoại về Mẫu Liễu Hạnh}

\begin{tabular}{|c|c|c|c|}
\hline & Dị bản a & Dị bản $b$ & Dị bản c \\
\hline $\begin{array}{l}\text { Thời điểm giáng } \\
\text { sinh lần đầu }\end{array}$ & $\begin{array}{l}\text { Thời vua Lê Thái Tổ } \\
(1428-1433)\end{array}$ & $\begin{array}{l}\text { Năm Thiên Hựu (1557) thời } \\
\text { vua Lê Anh Tông }\end{array}$ & $\begin{array}{l}\text { Năm Thiệu Bình thứ nhất } \\
\text { (1434) thời vua Lê Thái } \\
\text { Tông }\end{array}$ \\
\hline $\begin{array}{l}\text { Số lần và địa } \\
\text { điểm giáng } \\
\text { sinh/trần }\end{array}$ & $\begin{array}{l}\text { Hai lần } \\
\text { Lần 1: Đèo Ngang; } \\
\text { Lần 2: Đèo Tam } \\
\text { Điệp. }\end{array}$ & $\begin{array}{l}\text { Ba lần } \\
\text { Lần 1: Đầu thai vào nhà họ Lê } \\
\text { ở Vân Cát, Thiên Bản; } \\
\text { Lần 2: Giáng trần ở Vân Cát, } \\
\text { sau đó vân du ở Lạng Sơn, } \\
\text { Tây Hồ, Nghệ An; } \\
\text { Lần 3: Phố Cát, hiển linh ở } \\
\text { Sòng Sơn. }\end{array}$ & $\begin{array}{l}\text { Ba lần } \\
\text { Lần 1: Đầu thai vào nhà họ } \\
\text { Phạm ở Vi Nhuế, Ý Yên; } \\
\text { Lần 2: Vân Cát; } \\
\text { Lần 3: Làng Sóc, Tây Mỗ, } \\
\text { Hà Trung. }\end{array}$ \\
\hline $\begin{array}{l}\text { Tên cha mẹ } \\
\text { lúc đầu thai }\end{array}$ & & Lê Thái Công & $\begin{array}{l}\text { Phạm Đức Chính và Đoàn } \\
\text { Thị Phương }\end{array}$ \\
\hline $\begin{array}{l}\text { Tính danh } \\
\text { Tiên Chúa }\end{array}$ & $\begin{array}{l}\text { Công chúa } \\
\text { Liễu Hạnh }\end{array}$ & $\begin{array}{l}\text { Là̀n 1: Ở Thiên cung là Đệ } \\
\text { nhị công chúa Quỳnh Nương, } \\
\text { xuống hạ giới là Giáng Tiên; } \\
\text { Lần 2: Công chúa Liễu Hạnh, } \\
\text { Quỳnh Hoa. }\end{array}$ & $\begin{array}{l}\text { Lần 1: Ở Thiên cung là Đệ } \\
\text { nhị Tiên chúa Hồng Liên, } \\
\text { xuống hạ giới là Phạm Tiên } \\
\text { Nga; } \\
\text { Lần 2: Lê Thị Thắng; } \\
\text { Lần 3: Hoàng Thị Trinh. }\end{array}$ \\
\hline $\begin{array}{l}\text { Gia thất Tiên } \\
\text { chúa }\end{array}$ & $\begin{array}{l}\text { Không lấy chồng, } \\
\text { nhưng hai lần xuống } \\
\text { hạ giới sinh hai con, } \\
\text { đứa "thừa" (chân tay } \\
\text { sáu ngón), đứa } \\
\text { "thiếu" (chân tay bốn } \\
\text { ngón), một trong hai } \\
\text { đứa có Trạng Quỳnh. }\end{array}$ & $\begin{array}{l}\text { Lần 1: Lấy chồng là Đào } \\
\text { Lang, sinh một trai và một gái. } \\
\text { Lần 2: Lấy thư sinh làng Sóc, } \\
\text { Nghệ An, là kiếp sau của Đào } \\
\text { Lang, sinh một trai. }\end{array}$ & $\begin{array}{l}\text { Lần 1: Không lấy chồng; } \\
\text { Lần 2: Lấy chồng là Trần } \\
\text { Duy Đào, sinh một trai là } \\
\text { Nhâm và một gái là Hòa; } \\
\text { Lần 3: Lấy chồng là Mai } \\
\text { Thanh Lâm, sinh một trai là } \\
\text { Thanh Cổn. }\end{array}$ \\
\hline
\end{tabular}

Có thể nhận ra cả ba dị bản trên đây là tập hợp những tiên thoại lưu truyền trong dân gian, được các Nho sỹ "xâu chuỗi"/"gá lắp" thành một "chỉnh thể thống nhất", nhưng vẫn để lộ những "khớp nối" và "vết hàn", bởi trong đó mỗi vị tiên đều có thân phận và hành trạng khác nhau. Nói một cách khác, trong mỗi dị bản lại hàm chứa những tiểu dị bản, tác giả tạm quy ước thành tám tiểu dị bản là Dị bản a.1, Dị bản a.2, Dị bản b.1, Dị bản b.2, Dị bản b.3, Dị bản c.1, Dị bản $c .2$, và $\mathrm{Dị} \mathrm{bản} \mathrm{c} .3$. Căn cứ vào thời gian xuất hiện có thể thiết lập quan hệ giữa các dị bản theo Hình 3 .

\begin{tabular}{|c|c|c|}
\hline Chuyện lưu truyền & Đoàn Thị Điểm & \\
\hline Cát thần nũ lục & (như ở Phủ Nấp) & \\
\hline
\end{tabular}

Hình 3. Mối quan hệ giữa các dị bản về Thánh Mẫu Liễu Hạnh 
Ngoài các dị bản trên đây, các tác giả Trần Duy Phương và Chu Xuân Giao còn cho biết tại xã Trường Thịnh, huyện Úng Hòa, cách trung tâm Hà Nội 30km theo Quốc lộ $21 \mathrm{~B}$ có đền thờ Mẫu Thanh Sam (đúng hơn là đền thờ hai anh em Trần Quảng Uy và Trần Liễu Nương). Bản thần tích về vị Thánh Mẫu ở đây cũng có tên là Liễu Hạnh công chúa và là hoàng hậu của vua Lý. Tóm tắt như sau: Vào thời nhà Lý ở làng Quả Hồi, phủ Từ Liêm, phủ Quốc Oai, có vợ chồng ông Trần Minh Thiện và bà Nguyễn Thị Sương sống nhân hậu và phúc đức. Dù tuổi đã cao nhưng họ vẫn chưa có con, dẫu đã cầu tự nhiều nơi. Lòng thành của ông bà đã động tới trời cao, ông bà đã gặp được tiên ông chỉ cho địa linh để táng mả tổ, nhờ đó sinh được quý tử là Quảng Uy và sau đó là thứ nữ Liễu Nương (nhân giấc mộng thấy tiên ông trồng cây liễu lên bụng vợ). Tới tuổi trăng tròn, Liễu Nương trở thành cô gái xinh đẹp. Nhân một lần hai anh em du ngoạn kinh thành, vua Lý bắt gặp, rước nàng về cung, phong là Liễu Hạnh công chúa, sau đó lập làm hoàng hậu, còn anh nàng được phong làm tướng quân. Hai anh em Liê̂u Nương mấy phen giúp vua đánh giặc xâm phạm bờ cõi phía Nam, được vua nhiều lần ban thưởng, nhưng họ đều ban phát lại cho dân chúng. Sau đó hai anh em du ngoạn sơn thủy, về quê bái yết gia tiên, và lên núi Sài Sơn theo tiên ông về thượng giới. Bà mất vào ngày 03 tháng 3 và Ông mất vào ba ngày sau đó. Sau khi Ông Bà qua đời, dân chúng nhớ ơn lập đền thờ. Vua Lý phong người anh là Vĩ liệt hoằng tế linh đại vuơng, dân chúng gọi là Đức Thánh Cả và phong người em là Vuơng phi hoàng hậu Liê̂u Hạnh thuần mỹ công chúa, dân chúng gọi là Đức Thánh Mẫu (Chu, 2013, tr. 328-329).

Theo nghiên cứu này, bản thần tích trên không đáng tin cậy, bởi tác giả của nó Hàn lâm viện Đông các Đại học sĩ Nguyễn Bính, là một nhân vật kỳ bí. Chỉ không đầy một năm (Hồng Phúc nguyên niên (1572)), đã soạn tới 1,861 bản thần tích (Nguyễn, 1999), tính trung bình ông đã soạn năm bản thần tích trong một ngày. Thật khó tin vào thời điểm mà hành cung vua Lê vẫn còn ở đất Thanh Hóa, cuộc chiến với nhà Mạc vẫn đang hồi gay cấn, mà có người làm việc phi thường như vậy (kể cả trong điều kiện ông không bị ốm đau và thời tiết lúc nào cũng tốt). Theo chúng tôi, nhiều lắm cũng chỉ có thể xem đây là một sự trùng tên nhân vật, chứ không liên quan tới thần chủ của TNTM Tam phủ.

Trong tập 4 bộ Dictionnaire universel, historique et comparatif de toutes les religions $d u$ Monde, xuất bản năm 1851 tại Paris, lần đầu tiên xuất hiện mục từ "Bà Chúa Liễu Hạnh" (Bertrand, 1851). Nhằm đề cao Đức mẹ Maria, thông qua việc dựa trên những tư liệu xuyên tạc của các giáo sỹ phương Tây, tác giả cuốn từ điển đó đã xem "Liê̂u Hạnh là phụ nữ chơi bời ở một tỉnh phía Nam (của Đàng Ngoài), thường hát những bài ca thô tục, rồi bị mấy kẻ ghen tuông giết chết, ném xác xuống sông, sau khi chết người ta thờ bà'(!) (Chu, 2015, tr. 54). Chúng tôi không xem hai trường hợp "Mẫu Liễu Thanh Sam" và những xuyên tạc có dụng ý xấu của các giáo sỹ phương Tây như là những dị bản.

Về cơ bản, cả tám tiểu dị bản đều tương ứng với ba mô-típ tiên thoại chính như: Trích tiên: Tiên mắc lỗi bị đày xuống hạ giới; Du tiên/thi tiên: Tiên chán tiên giới xuống trần ngao du sơn thủy, ngâm vịnh thơ phú; và Giáng tiên: Tiên giáng trần tác phúc, tác họa, dân chúng kính và sợ nên phải lập đền thờ (tương tự như những phân tích của PGS. Nguyê̂n Duy Hinh về Vân Cát thần nũu của nữ sỹ Đoàn Thị Điểm) 
(Nguyễn, 2003, tr. 735-739; Nguyễn, 2007, tr. 968-970). Ở Dị bản b.3 còn có thêm trận "Sùng Sơn đại chiến". Theo đó, trước trận giao chiến, các pháp sư Nội Đạo tràng đã lừa lấy mất phép quyết nên Tiên chúa bị bắt, may nhờ Phật Tổ cứu thoát nên đã quy y Phật pháp-nói theo lời PGS. Nguyễn Duy Hinh là "Mẫu được Phật Tổ đưa vào chùa “cải tạo"” (Nguyễn, 2007, tr. 970). Chi tiết này có thể do giới sư tăng Phật giáo thêm vào nhằm đề cao đạo Phật sau mấy thế kỷ "lép vế" và đang cố gượng hồi phục.

Trong các dị bản nói trên, các Dị bản a và Dị bản $b$ đều đưa thời điểm Tiên chúa giáng thế vào các thập niên thứ hai và ba của thế kỷ $X V$ là quá sớm, ngoại trừ một chi tiết có thể xem là phù hợp với chính sử: Ngày 07 tháng Giêng năm Kỷ Dậu (1429), vua Lê Thái tổ không chọn hoàng trưởng tử Tư Tề, mà lập con thứ là Lương quận công Nguyên Long làm Hoàng Thái tử (Lê, Phan, \& Ngô, 2003b, tr. 463). Việc hoàng trưởng tử bị phế truất có thể do Tư Tề bị điên hoặc do hoàng hậu Phạm Ngọc Trần báo mộng? Tuy nhiên, điều đó lại không phù hợp với một loạt những tài liệu liên quan tới đời sống tôn giáo, tín ngưỡng của người Việt đương thời. Cụ thể, những tiên thoại này không bắt gặp trong Việt điện $u$ linh tập và Lĩnh Nam chich quái-có thể xem là những bộ sưu tập thần tích sớm nhất của nước ta, được Trần Thế Pháp và Lý Tế Xuyên biên soạn vào các thế kỷ XIV và thế kỷ XV, được Vũ Quỳnh, Kiều Phú, và Nguyễn Văn Chất bổ soạn vào nửa sau thế kỷ $X V$. Trong hai bộ sưu tập "thần tích" vừa nêu có chép sự tích của cả trăm vị thần từ thời Hồng Bàng đển thời Hồng Đức, có cả một số vị gốc Trung Quốc và Chăm $\mathrm{Pa}$, thậm chí có cả những vị không rõ danh tính, ấy thế mà không đả động gì đến một vị Thánh Mẫu linh thiêng nức tiếng xa gần như Liễu Hạnh (Lý, 1994; Trần, 2011). Mục "Đền chùa" trong sách $\hat{O}$ Châu cận lục của Dương Văn An viết năm Ất Mão (1555) đề cập tới 15 đền chùa từ Quảng Bình vào tới Bắc Quảng Nam, cũng không có ngôi đền nào dưới chân dãy Hoành Sơn (Dương, 2001). Trong Truyền kỳ mạn luc của Nguyễn Dữ viết vào khoảng nửa đầu thế kỷ XVII, mặc dù có chuyện Tù Thức lấy vơ tiên, nhưng không có chuyện về Mẫu Liễu (Nguyễn, 2013). Không thể hình dung một nhân vật nổi tiếng tầm cỡ như Mẫu Liễu Hạnh lại không để lại một ấn tượng nào với các học giả uyên bác của Đại Việt trong suốt mấy thế kỷ, từ thế kỷ XV đến thế kỷ XVII.

Mặt khác, từ giữa thế kỷ XVI, các giáo sỹ, các thương gia, và lữ khách phương Tây bắt đầu đến Việt Nam, ở cả Đàng Trong và Đàng Ngoài. Nhiều người trong số họ ở lại trong nhiều năm, dành nhiều thời gian tìm hiểu phong tục - tập quán, tôn giáo, và tín ngưỡng ở người Việt để phục vụ cho công cuộc truyền giáo/kinh doanh của mình. Các giáo sỹ thường gửi báo cáo về Cha bề trên ở chính quốc về tình hình tôn giáo, tín ngưỡng để xin chỉ đạo và cung cấp tài chính. Một số còn xuất bản thành sách để giới thiệu với độc giả phương Tây về vùng đất mà họ đã nhiều năm khám phá như là những phát kiến. Trong số những ấn phẩm của họ về Vương quốc Đàng Ngoài đã có bốn cuốn được dịch ra tiếng Việt trong thời gian qua. Đó là Dictionarium AnnamiticumLusitanum-Latinum (Từ điển Annam-Lusitan-Latinh, thường gọi là "Từ điển Việt-BồLa") (de Rhodes, 1991), Histoire du Royaume de Tunquin (Lịch sử Vương quốc Đàng Ngoài) (de Rhodes, 2016), Relation nouvelle et singulière du Royaume de Tunquin (Tập du ký mới và kỳ thú về Vương quốc Đàng Ngoài) (Tavernier, 2007), và A Description of the Kingdom of Tonqueen (Mô tả Vương quốc Đàng Ngoài) (Baron, 1685). Trong các cuốn sách nói trên, các giáo sỹ và thương gia đã dành những chương mục giới thiệu khá chi tiết về sinh hoạt tôn giáo, tín ngưỡng của cư dân Đàng Ngoài từ thập niên 30 đến 
thập niên 60 của thế kỷ XVII như: Các hoạt động bói toán, đồng bóng, địa lý (phong thủy), tục thờ Bà mụ/12 Bà mụ, tục thờ Tống phi ở cửa Cờn (Cửa Chúa), tục làm nhà mồ canh mộ cha mẹ (nhà xe)... Tóm lại là "thóc mách" đủ thứ chuyện, nhưng tuyệt nhiên không đề cập gì tới TNTM. Điều đó chứng tỏ, cho đến giữa thế kỷ XVII, TNTM mới ra đời ở Đàng Ngoài và vẫn chưa phổ biến trong dân chúng nên chưa gây chú ý gì tới các giáo sỹ, thương gia, và du khách phương Tây, trong đó có Baron là con của một thương gia Hà Lan và một phụ nữ bản xứ, được sinh ra và có nhiều năm làm việc cho Công ty Đông Ấn Anh ở Đàng Ngoài.

Trong số các dị bản nói trên, đáng chú ý hơn cả là Dị bản b-Vân Cát thần nũ luc, của Đoàn Thị Điểm, bởi đây là tư liệu thành văn sớm nhất về Mẫu Liễu Hạnh (khoảng thập niên 30 đến thập niên 40 thế kỷ XVIII). Nội dung của câu chuyện cũng phù hợp với Vân Cát Lê gia ngọc phả do Nguyễn Quốc Trinh soạn vào năm Vĩnh Tộ thứ 5 (1623) (Nguyễn, 2003, tr. 724), cũng như cuốn gia phả bằng đồng phát hiện ngày 12 tháng 4 năm 1939 trong thời gian tu bổ đền Sòng (Lagrèze, 1941, tr. 1-15). Theo đó, nhân vật tiên chúa Liễu Hạnh trong câu chuyện nói trên được xây dựng trên cơ sở một nguyên mẫu có thật là cô Lê Thị Thắng, dòng dõi hoàng tộc (chắt của vua Lê Nhân Tông, cháu của hoàng tử Lê Tư Vĩnh). Khi Mạc Đăng Dung cướp ngôi, hoàng tử Vĩnh chạy về làng Vân Cát (An Thái, Vụ Bản) lánh nạn. Con trai của hoàng tử Vĩnh là Tư Thắng chỉ sinh được một người con gái là Lê Thị Thắng, tức Giáng Tiên. Vì cô Thắng chết trẻ, không có người nối dõi, nên bố mẹ đã đem hết điền sản cúng hậu cho cô (Lagrèze, 1941, tr. 14). Điều này cũng phù hợp với quan niệm dân gian, những cô gái chết trẻ thường rất thiêng, vì vậy người ta cúng kiếng rất trọ̣ng thể và dựa vào những mô-típ tiên thoại có sẵn, mô phỏng, và thêu dệt thành huyền thoại về tiên chúa Liễu Hạnh.

Những chuyện loại này thường có tính dị bản rất cao, sai biệt qua mỗi người kể/lần kể là chuyện thường gặp. Tuy nhiên, Dị bản $\mathrm{b}$ có "cố định" lại bằng những mốc thời gian cụ thể có thể làm căn cứ như Mẫu sinh vào năm Thiên Hưu tức 1557, Tiên chúa xuớng họa với ho Phùng vìa đi sú ở Trung Quốc về (theo chính sử là ngày 15 tháng 12 năm Mậu Tuất, tức ngày 11 tháng 1 năm 1599). Rồi vào những năm thuộc niên hiệu Cảnh Trị, tức từ năm 1663 đến năm 1671, vua cho Tiên chúa là yêu quái, sai lính Vũ Lâm đến phá đền. Tiên chúa làm phép cho bệnh dịch tràn lan và báo mộng cho dân chúng xin triều đình tái lập đền thờ. Nhà vua ưng chuẩn và sắc phong nàng làm $M \tilde{a}$ Hoàng công chúa. Có lần Tiên chúa còn âm phù giúp nhà vua đánh thắng giặc nên được gia phong Chế Thắng Hòa Diệu đại vuơng.

Điều này là hợp logic của việc hình thành các hiện tượng tín ngưỡng dân gian. Với những lần giáng trần theo mô-tip trích tiên-tiên mắc lỗi, bị phạt đầu thai vào một gia đình hiếm muộn, lớn lên là một cô gái xinh đẹp, công dung ngôn hạnh, lấy chồng, sinh con... Tóm lại là chẳng có phép thuật, không khác người bình thường-không ai thờ. Với mô-tip du tiên/thi tiên-Tiên chán tiên giới xuống hạ giới ngao du sơn thủy, ngâm vịnh với văn nhân, tài tử.... Tuy có phép đi mây về gió, biến hóa... nhưng vô hại, cũng không ai thờ phụng (chỉ có Khuất Nguyên được thờ vì trung nghĩa). Chỉ có mô-tip giáng tiên-Tiên xuống hạ giới tác phúc, tác họa, dân chúng kính và sợ nên mới lập đền thờ. Vì vậy, theo Dị bản b, việc Tiên Chúa báo mộng bắt dân chúng lập đền thờ ở Sòng 
Sơn vào nửa đầu thế kỷ XVII là khá hợp lý. Cũng theo đó, nơi phát sinh của TNTM là Sòng Sơn, Thanh Hóa, những nơi khác là thờ vọng từ Sòng Sơn (Sùng Sơn vọng tì̀) (Nguyễn, 2003, tr. 730). Vân Cát, Phủ Dày là "quý hương" không có nghĩa là nơi đầu tiên xuất phát hiện tượng thờ Mẫu. Hoàn toàn chưa bắt gặp cơ sở thờ Mẫu nào có biển Vân Cát/Vân Hương/Tiên Hương vọng tùt. Việc vua Lê Huyền Tông (Cảnh Trị) phong cho Tiên chúa là Mã Hoàng công chúa, rồi Chế Thắng Hòa Diệu đại vương như một sự công nhận chính thức cho loại hình tín ngưỡng này, và là cơ sở quan trọng để nó lan tỏa ra khắp các vùng, miền từ những thập niên cuối thế kỷ XVII.

\subsubsection{Căn cú vào bối cảnh lịch sủ̉}

Như đã nêu ở trên, hầu như các nhà nghiên cứu về TNTM đều cho sự ra đời của loại hình tín ngưỡng này gắn với sự khủng hoảng của ý thức hệ Nho giáo và là phản ứng tự vệ trước sự xâm nhập của Ki tô giáo. Cũng đã có một vài nhà nghiên cứu chú trọng hơn tới sự manh nha của kinh tế hàng hóa. Trong các huyền tích về Mẫu Liễu, có một chi tiết rất đáng chú ý là Tiên chúa "mở quán bán hàng". "Mẫu là biểu tương của các cô gái đẹp bán quán của nền thuoong nghiệp Việt Nam vìa có chút hé mở ở các thế kỷ XVI, XVII, và XVIII" (Trần, 2017, tr. 113 ); “....tục thò̀ Mẫu Liễu là kết quả của nền kinh tế hàng hóa thế kỷ XVI-XVIII và lên đồng cầu Thánh Mẫu ban lộc, ban tài cũng chì là một thế ứng xử của các tín đồ thương nghiệp đối với Mẫu mà thôi, đó là cách úng xủ mang bản sắc thưc dụng của tầng lớp thương nhân" (Nguyễn, 2017, tr. 93). Trả lời phỏng vấn của Đài Truyền hình Hà Nội tối ngày 03 tháng 12 năm 2016 (ngay sau khi nhận tin thực hành TNTM được cộng nhận là Di sản văn hóa phi vật thể đại diện của nhân loại), GS. Ngô Đức Thịnh cũng lưu ý "Mẫu là vị thần của thị dân, của cu dân buôn bán" và "là vị thần thwơng nghiệp".

Rõ ràng, đã có một nhận thức mới tiệm cận với hiện thực, bởi tín ngưỡng thờ mẹ của cư dân nông nghiệp chủ yếu liên quan tới thờ nữ thần và mẫu thần nói chung, chứ chưa phải là Mẫu Tam phủ. Nền nông nghiệp lúa nước chủ yếu đáp ứng nhu cầu về lương thực và thỏa mãn nhu cầu tối thiểu của cuộc sống-cái ăn (no cái bụng), trong khi cuộc sống càng phát triển, nhu cầu của con người càng tăng cao, bên cạnh nhu cầu vật chất (tanggible culture) còn có nhu cầu về văn hóa tinh thần (intangible culture). Nền kinh tế tiểu nông với cây lúa nước là chủ đạo không thể thỏa mãn nhiều nhu cầu khác của cuộc sống, trong đó có không ít những nhu cầu mà mỗi người/gia đình không thể tự túc được mà phải thông qua trao đổi mới có. Điều đó đã dẫn tới sự hình thành nền thương nghiệp tiền công nghiệp. Đặc trưng của nền thương nghiệp tiền công nghiệp là quy mô hàng hóa trao đổi thường không lớn, về cơ bản số hàng hóa chi vì̀a môt đôi quang gánh để tiện cơ động "nay đây, mai đó”, vì vậy nó phù hơp với nũ giới hơn nam giới (trừ buôn trâu, buôn luồng) và hình thành nên một tầng lớp nư tiểu thuơng, tất bật nay chợ hôm, mai chợ huyện, ngày kia chợ phủ... và có cả những trường hợp băng đèo, vượt suối trẩy hàng ở những vùng miền xa hơn với hy vọng có những món hời, đem lại hiệu quả cao hơn. Trong những chuyến trẩy hàng xuôi ngược, dọc ngang như vậy, họ "hóng hớt" đủ thứ chuyện, nhưng chuyện mà họ mẫn cảm hơn cả vẫn là những chuyện về ma, quỷ, hay thần thánh. Đó cũng là lý do tính dị bản của huyền thoại nói chung và huyền thoại về Mẫu Liễu nói riêng rất phong phú. Nói một cách khác, chính tầng lớp 
thương nữ đã cung cấp "tư liệu” để các nhà nho bình dân nhào nặn nên hình tượng Thánh Mẫu Liễu Hạnh.

Mặt khác, hoạt động buôn bán thường rất "phập phù", tàng ẩn nhiều yếu tố may rủi và lời lãi thất thường, nên nhu cầu về sự phù hộ và độ trì của thần thánh là rất lớn. Vả lại, thân gái dặm trường, họ luôn phải đối diện với đủ thứ nguy cơ rình rập-thú dữ, cướp bóc, lừa lọc, bão giông... nên nhu cầu về một vị thánh có cùng giới tính để có thể cảm thông, che chở, bênh vực cho thân phận liễu yếu đào tơ, và phù trợ cho họ luôn được buôn may, bán đắt, tài lộc dồi dào... trở nên cấp thiết. Có thể nhận ra khung cảnh khá nhộn nhịp của nền thương nghiệp Đại Việt trong thế kỷ XVII-XVIII thông qua nhu cầu tiền tệ trong các thế kỷ XVI-XVIII. Các triều Lê và Mạc đua nhau đúc tiền. Riêng triều Cảnh Hưng (1740-1786) đã có tới hàng chục loại tiền khác nhau, trở thành "một hiện tượng hiếm có trong lịch sử phát triển tiền tệ thế giới” (Phạm, 2005, tr. 47).

\subsubsection{Căn cúv vào các đạo sắc phong}

Sắc phong như một chứng cứ vật chất về sự tồn tại của các hình thái thờ phụng. Hay nói như Chu Xuân Giao "là căn cước lịch sử" và là "chứng tín quan trọng" xác nhận về sự hiện diện của một hình thái thờ phụng. Về phương diện này, cho đến nay, đã tìm thấy hàng chục đạo sắc phong của các triều đại Hậu Lê, Tây Sơn, và Nguyễn cho Thánh Mẫu Liễu Hạnh. Riêng tại Phủ Dày hiện lưu giữ 21 bản (Phủ Tiên Hương 14 bản và Nhà thờ Trần Lê bảy bản). Đạo sắc phong cho Mẫu Liê̂u sớm nhất có niên đại Dương Hòa (Lê Thần Tông) đệ bát niên, tức năm 1642 hiện không còn nguyên vật, chỉ có bản sao lưu trữ tại Thư viện của Viện nghiên cứu Hán Nôm (ký hiệu AD.a.16/29) vốn từ kho tư liệu của Viện Viễn Đông bác cổ (EFEO), được thực hiện vào khoảng từ năm 1911 đến năm 1917 (Chu, 2018). Kết hợp với bản Vân Cát Lê gia ngoc phả của Nguyễn Quốc Trinh (biên soạn vào năm 1623) và chi tiết Mẫu Liễu gặp Phùng Khắc Khoan (đầu năm 1599), có thể khẳng định tục thờ Mẫu xuất hiện sớm nhất là vào đầu thế kỷ XVII.

\section{KẾT LUẬN}

Từ sự phân tích các dữ liệu huyền thoại và bối cảnh lịch sử, có thể đi tới một số nhận định sau:

Một là, cần phân biệt hai phạm trù "TNTM" nói chung và "TNTM Tam phủ" với vị Thần chủ là Thánh Mẫu Liễu Hạnh nói riêng. TNTM nói chung có thể ra đời sớm và gắn với khát vọng phồn thực của cư dân nông nghiệp, còn TNTM tam phủ là tục thờ vị Nữ thần Tài Lộc của tầng lớp nữ tiểu thương, gắn với nhu cầu về một vị nữ thần phù trợ, "ban tài phát lộc" cho những người làm nghề buôn bán. TNTM Tam phủ không thể xuất hiện sớm hơn thời điểm đầu thế kỷ thứ XVII, bởi các nguồn tài liệu thư tịch của Việt Nam và Phương Tây thời đó đều chưa đề cập tới huyền thoại và hiện tượng thờ Mẫu Liễu ở Đàng Ngoài. Liên quan đến vấn đề này, tôi đồng tình với PSG. Nguyễn Duy Hinh khi ông quan niệm cái nôi của tín ngưỡng thờ Mẫu Tam phủ là Sòng Sơn (Thanh Hóa) chứ không phải là Phủ Dày hay Phủ Nấp (Nam Định) (Nguyễn, 2003, tr. 739). 
Hai là, như vậy, tương tự như các vị thần linh khác, Mẫu Liễu là sản phẩm do con người sáng tạo ra để phục vụ nhu cầu của chính họ (đương nhiên là do họ tự huyễn hoặc chính mình). Từ cơ sở ban đầu là thờ Mẫu Liê̂u, thần điện (pantheon) của TNTM không ngừng được bổ sung thêm những lớp thờ phụng mới, hình thành Thần điện Tam/Tứ phủ và lựa chọn hình thức nghi lễ đặc trưng mang đậm màu sắc saman giáolên đồng.

Ba là, TNTM chủ yếu là tín ngưỡng của tầng lớp cư dân buôn bán, chính vì vậy khi đất nước vận hành nền kinh tế theo cơ chế thị trường, nó đã bùng phát mạnh mẽ cả về cơ sở thờ tự và hoạt động lên đồng-hầu bóng. Cũng chính vì vậy, việc UNESCO công nhận thực hành TNTM Tam phủ là Di sản văn hóa phi vật thể đại diện của nhân loại vừa là một tin vui vừa đem lại một sự quan ngại sâu sắc về phương diện quản lý Nhà nước, vì ranh giới giữa tín ngưỡng và mê tín của hoạt động lên đồng rất mong manh (Nguyệt, 2016). Không ít các cơ sở thờ Mẫu, các thanh đồng, và tín đồ của loại hình tín ngưỡng này sẽ xem đó như một sự "hợp pháp hóa"cho hoạt động lên đồng, tổ chức hầu đồng tràn lan, gây lãng phí về thời gian, tiền của, và sức khỏe của tín đồ. Cần hết sức cảnh giác với tình trạng "thương mại hóa" hoạt động tâm linh nói chung và lên đồng nói riêng. Cần lưu ý sâu sắc huấn thị của Phó Thủ tướng Vũ Đức Đam trong buổi lễ đón Bằng Vinh danh Thực hành Tín ngưỡng thờ Mẫu Tam phủ của UNESCO tại Nam Định, tối ngày 02 tháng 4 năm 2017 “Cần để Tín ngương thờ Mẫu Tam phủ được thưc hiện, được trao truyền đúng với ý nghĩa, bản sắc rất tốt đẹp, rất đặc sắc vốn có. Không để bị làm sai lẹch, biến tướng, và bị làm tầm thuờng hóa, thuơng mại hóa".

Bốn là, trong các công trình về Đạo Mẫu ở Việt Nam, GS. Ngô Đức Thịnh đã hơn một lần khẳng định "Đìng đi tìm sự xác thực lịch sử ở các hiện tương tôn giáo-tín ngương, vì ở đó chỉ có sụ xác tín. Mà với con người nhiều khi sự xác tín còn cao hơn và quan trọng hơn cả sự xác thục" (Ngô, 2003, tr. 110; Ngô, 2009, tr. 119). Thiết nghĩ, nhận định trên đây không phù hợp với tinh thần "hoài nghi tất cả" của những nhà khoa học. Đứng trên quan điểm chủ nghĩa vô thần, nhiệm vụ hàng đầu của những người nghiên cứu tôn giáo, tín ngưỡng là phải giải thiêng những điều huyền bí và khai sáng cho quần chúng để họ không sa lầy vào mê tín dị đoan.

\section{TÀI LIẸU THAM KHẢO}

Baron, S. (1685). Mô tả Vương quốc Đàng Ngoài (A. T. Hoàng, Dịch). Hà Nội, Việt Nam: NXB. Khoa học Xã hội.

Bertrand, F. M. (1851). Dictionnaire universel, historique et comparatif de toutes les religions du Monde (Vol. 4). Paris, France: Hachette Livre.

Bùi, X. Đ. (2015). Dân tộc Kinh (Việt). Trong Viện Hàn lâm Khoa học Xã hội Việt Nam, Các dân tộc ở Việt Nam (Tập 1, tr. 87-400). Hà Nội, Việt Nam: NXB. Chính trị Quốc gia.

Chu, X. G. (2010). Quảng Cung linh từ trong nguồn tư liệu Hán Nôm: Sơ bộ tổng quan thời điểm ấn tống Cát thiên tham thế thực lục (1913). Trong Đ. T. Ngô, Phủ Quảng Cung trong hệ thống đạo Mẫu Việt Nam (tr. 90-153). Hà Nội, Việt Nam: NXB. Tôn giáo. 
Chu, X. G. (2013). Mẫu Liễu Thanh Sam: Bước đầu nghiên cứu về nhóm văn bản chép sự tích Liễu Hạnh công chúa xuất hiện từ thời Lý. Trong Đ. T. Ngô, Văn hóa thờ Nũ thần-Mẫu ở Việt Nam và châu Á-bản sắc và giá trị (tr. 326-341). Hà Nội, Việt Nam: NXB. Thế giới.

Chu, X. G. (2015). Mẫu Liễu trong cá tác phẩm thời kỳ đầu tiên của người phương Tây. Nghiên cứu Tôn giáo, 8(146), 48-77.

Chu, X. G. (2018). Căn cước lịch sử của Thánh Mẫu: Phát hiện và luận giải đạo sắc phong cổ nhất mang niên đại 1683 cho Liễu Hạnh công chúa hiện vẫn còn nguyên tại Phủ Giầy ở Nam Định. Tạp chí Nghiên cứu và Phát triển, 5(148), 24-55.

Chu, X. G., \& Phan, L. H. (2008). Truy tìm những khoảnh chân thực riêng lẻ: Về thời điểm xuất hiện của Phủ Tây Hồ từ góc nhìn nhân loại học lịch sử. Tạp chí Văn hóa Dân gian, 3(117), 21-44.

de Rhodes, A. (1991). Tù điển An nam-Lusitan-Latinh (L. Thanh, X. V. Hoàng, \& Q. C. Đỗ, Dịch). Hà Nội, Việt Nam: NXB. Khoa học Xã hội.

de Rhodes, A. (2016). Lịch sủ Vưong quốc Đàng Ngoài (N. Hồng, \& K. X. Nguyễn, Dịch). Hà Nội, Việt Nam: NXB. Khoa học Xã hội.

Dương, V. A. (2001). Ô Châu cận luc (K. T. Nguyễn, Dịch). Huế, Việt Nam: NXB. Thuận Hóa.

Đặng, V. B. (2005). Thờ Mẫu-tín ngưỡng truyền thống bản địa Việt Nam. Tạp chí Dân tộc học, (1), 8-12.

Đoàn, T. Đ. (2013). Truyền kỳ tân phả (L. C. Ngô, \& V. G. Trần, Dịch). TP. Hồ Chí Minh, Việt Nam: NXB. Trẻ.

Lagrèze, A. (1941). Documents concernant le Temple Dên-Song, au Thanh-Hoa: Bulletin des Amis du Vieux Huê (BAVH). Trong N. T. Đặng, Nhũng người bạn cố đô Huế (Tập 27, tr. 6-28). Huế, Việt Nam: NXB. Thuận Hóa.

Lê, V. H., Phan, P. T., \& Ngô, S. L. (2003a). Đại Việt sử ký toàn thu (Tập 1). Hà Nội, Việt Nam: NXB. Văn hóa Thông tin.

Lê, V. H., Phan, P. T., \& Ngô, S. L. (2003b). Đại Việt sủ ký toàn thu (Tập 2). Hà Nội, Việt Nam: NXB. Văn hóa Thông tin.

Lý, T. X. (1994). Việt điện u linh tập. Hà Nội, Việt Nam: NXB. Văn học.

Ngô, Đ. T. (2009). Đạo Mẫu Việt Nam (Tập 1). Hà Nội, Việt Nam: NXB. Tôn giáo.

Ngô, Đ. T. (2010). Mấy nhận thức chung về đạo Mẫu Việt Nam. Trong Đ. T. Ngô (Ed.), Phủ Quảng Cung trong hệ thống đạo Mẫu Việt Nam (tr. 16-26). Hà Nội, Việt Nam: NXB. Tôn giáo.

Ngô, Đ. T. (2016). Đạo Mẫu, tính độc đáo dân tộc và giá trị nhân loại. Trong V. S. Võ, Đ. T. Ngô, \& V. L. Nguyễn (Eds.), Tín ngương thờ Mẫu ở Nam Bộ: Bản sắc và giá trị (tr. 3-12). TP. Hồ Chí Minh, Việt Nam: NXB. Đại học Quốc gia TP. Hồ Chí Minh.

Nguyễn, D. (2013). Truyền kỳ mạn lục (K. N. V. T. Trúc, Dịch). TP. Hồ Chí Minh, Việt Nam: NXB. Trẻ 
Nguyễn, D. H. (2003). Người Việt Nam với Đạo giáo. Hà Nội, Việt Nam: NXB Khoa học Xã hội.

Nguyễn, D. H. (2007). Một số bài viết về Tôn giáo học. Hà Nội, Việt Nam: NXB Khoa học Xã hội.

Nguyễn, Đ. C. (2000). Kho tàng truyện cổ tích Việt Nam (Tập 4). Hà Nội, Việt Nam: NXB. Giáo dục.

Nguyễn, Đ. D. (2001). Các hình thái tín nguõng tôn giáo ở Việt Nam. Hà Nội, Việt Nam: NXB. Văn hóa Thông tin.

Nguyễn, H. M. (1999). Góp thêm tư liệu mới vào việc tìm hiểu tác giả Nguyễn Bính. Tạp chí Hán Nôm, 1(38), 58-62.

Nguyễn, N. M. (2017). Nghi lễ lên đồng, lịch sủ và giá trị. Hà Nội, Việt Nam: NXB. Hà Nội.

Nguyệt, H. (2016). Tín ngưỡng - Mê tín: Đâu là ranh giới? Trong C. B. Nguyễn, \& T. L. Từ (Eds.), Tín ngương thờ Mẫu Tam phủ của người Việt, hành trình đến Di sản nhân loại (tr. 264-272). Hà Nội, Việt Nam: NXB. Thế giới.

Phạm, Đ. M. (2016). Lạm bàn về niên biểu tục thờ Mẫu và cá tính "Nam Bộ" trong di sản đình miếu-lăng tẩm nữ quý tộc Nam bộ thời cận đại. Trong $\mathrm{V}$. S. Võ, Đ. T. Ngô, \& V. L. Nguyễn (Eds.), Tín nguỡng thờ Mẫu ở Nam Bộ: Bản sắc và giá trị (tr. 28-43). TP. Hồ Chí Minh, Việt Nam: NXB. Đại học Quốc gia TP. Hồ Chí Minh.

Phạm, Q. Q. (2005). Tiền kim loại Việt Nam. Hà Nội, Việt Nam: NXB. Hà Nội.

Tavernier, J. B. (2007). Tập du ký mới và kỳ thú về Vương quốc Đàng Ngoài (T. L. Lê, Dịch). Hà Nội, Việt Nam: NXB. Thế giới.

Trần, Q. V. (2017). Về việc phục hồi phát huy làm giàu lễ hội Phủ Dầy. Trong C. B. Nguyễn, \& T. L. Từ (Eds.), Tín ngữ̛ng thờ Mẫu Tam phủ của nguời Việt, hành trình đến Di sản nhân loại (tr. 102-120). Hà Nội, Việt Nam: NXB. Thế giới.

Trần, T. P. (2011). Lĩnh Nam chích quái (Q. Vũ, P. N. C. Kiều, G. K. Đinh, N. S. Nguyễn, Dịch). TP. Hồ Chí Minh, Việt Nam: NXB. Trẻ.

Tù hải. (1979). Thượng Hải, Trung Quốc: Thượng Hải Từ thư Xuất bản xã. 